\title{
Copper tolerance of the thermoacidophilic archaeon Sulfolobus metallicus: possible role of polyphosphate metabolism
}

\begin{abstract}
Correspondence
Carlos A. Jerez

cjerez@uchile.cl
\end{abstract}

Received 31 May 2005

Revised 17 October 2005

Accepted 24 October 2005
Francisco Remonsellez, Alvaro Orell and Carlos A. Jerez

Laboratory of Molecular Microbiology and Biotechnology, Department of Biology, Faculty of Sciences, University of Chile, Santiago 1, Casilla 653, Santiago, Chile

It has been postulated that inorganic polyphosphate (polyP) and transport of metal-phosphate complexes could participate in heavy metal tolerance in some bacteria. To study if such a system exists in archaea, the presence of polyP was determined by the electron energy loss spectroscopy (EELS) procedure and quantified by using specific enzymic methods in Sulfolobus acidocaldarius, Sulfolobus metallicus and Sulfolobus solfataricus. All three micro-organisms synthesized polyP during growth, but only $S$. metallicus greatly accumulated polyP granules. The differences in the capacity to accumulate polyP between these archaea may reflect adaptive responses to their natural environment. Thus, S. metallicus could grow in and tolerate up to $200 \mathrm{mM}$ copper sulfate, with a concomitant decrease in its polyP levels with increasing copper concentrations. On the other hand, S. solfataricus could not grow in or tolerate more than 1-5 mM copper sulfate, most likely due to its low levels of polyP. Shifting $S$. metallicus cells to copper sulfate concentrations up to $100 \mathrm{mM}$ led to a rapid increase in their exopolyphosphatase (PPX) activity which was concomitant in time with a decrease in their polyP levels and a stimulation of phosphate efflux. Furthermore, copper in the range of $10 \mu \mathrm{M}$ greatly stimulated PPX activity in cell-free extracts from S. metallicus. The results strongly suggest that a metal tolerance mechanism mediated through polyP is functional in members of the genus Sulfolobus. This ability to accumulate and hydrolyse polyP may play an important role not only in the survival of these micro-organisms in sulfidic mineral environments containing high toxic metals concentrations, but also in their applications in biomining.

\section{INTRODUCTION}

Polyphosphates (polyP) are present in most organisms including bacteria, archaea and eukaryotes (Kornberg et al., 1999). PolyP is a linear polymer of hundreds of orthophosphate residues linked by phosphoanhydride bonds that has a variety of physiological functions, such as serving as a reservoir of phosphate, substitution for ATP in kinase reactions, serving as a chelator of metals, and adaptation to different stress conditions (Kornberg et al., 1999). The main enzyme involved in the biosynthesis of polyP is polyphosphate kinase (PPK), which catalyses the reversible conversion of the terminal phosphate of ATP into polyP (Akiyama et al., 1992). An exopolyphosphatase (PPX), on the other hand, is known to hydrolyse polyP, liberating inorganic phosphate $\left(\mathrm{P}_{\mathrm{i}}\right)$ (Akiyama et al., 1993). These enzymes have been purified from Escherichia coli and their genes have been identified in several bacteria (Kornberg et al., 1999; Alvarez \& Jerez, 2004).

Abbreviations: $\mathrm{P}_{\mathrm{i}}$, inorganic phosphate; polyP, polyphosphate; PPK polyphosphate kinase; PPX, exopolyphosphatase.
One of the proposed mechanisms for metal tolerance is the sequestration of metal cations by polyP (Kornberg et al., 1999). Many heavy metal resistance systems involve either an active efflux or a detoxification of metal ions by different transformations (Silver \& Phung, 1996). For copper, these include intracellular complexation, decreased accumulation, extracellular complexation or sequestration in the periplasm (Rouch et al., 1989; Harwood \& Gordon, 1994). It has also been proposed that the hydrolysis of polyP detoxifies the metals (Aiking et al., 1984; Keasling, 1997). Van Veen (1997) has shown that the inorganic phosphate transport system (Pit) in Escherichia coli and Acinetobacter johnsonii can reversibly transport metal phosphates. Keasling \& Hupf (1996), using genetically engineered strains of E. coli, obtained results indicating that not only a large quantity of intracellular polyP is important for tolerance to heavy metals but also the ability to synthesize and degrade polyP. Based on these results and those mentioned above, Keasling (1997) proposed a model in which the intracellular cation concentration in bacteria would regulate the activity of PPX, which would in turn degrade polyP, and the $\mathrm{P}_{\mathrm{i}}$ generated 
accompanied by cation transport would be removed from the cell through the Pit system. We have recently found that Acidithiobacillus ferrooxidans, a micro-organism that can tolerate very high concentrations of heavy metals in its normal environment, normally accumulates high amounts of polyP granules and that the levels of intracellular polyP are greatly decreased when the bacterium is grown in or shifted to $100 \mathrm{mM} \mathrm{Cu}^{2+}$. In the presence of this metal, PPX activity and $\mathrm{P}_{\mathrm{i}}$ efflux greatly increased, supporting a model for metal tolerance mediated through polyP (Alvarez \& Jerez, 2004).

Related to archaeal copper resistance mechanisms, some metal efflux pumps have been identified in the genomes of archaea (Pedone et al., 2004). The P-type CPX-ATPases are responsible for the transport of heavy metal ions in all kinds of organisms. One of the two CPX-ATPases of Sulfolobus solfataricus has recently been isolated and characterized (Deigweiher et al., 2004). In Ferroplasma acidarmanus the Ferl copper resistance (cop) loci (Ettema et al., 2003), which include genes encoding a putative transcriptional regulator $(\operatorname{cop} Y)$, a putative metal-binding chaperone $(\operatorname{cop} Z)$ and a putative copper-transporting P-type ATPase $(\operatorname{cop} B)$ have been described (Baker-Austin et al., 2005). By transcription analyses the authors demonstrated that $\operatorname{cop} Z$ and $\operatorname{cop} B$ are co-transcribed, and that the transcript levels increase significantly in response to exposure to high levels of $\mathrm{Cu}^{2+}$ ions, suggesting that the transport system is operating for copper efflux.

In archaea, polyP has been reported only in Methanosarcinae (Scherer \& Bochem, 1983) and in Sulfolobus acidocaldarius (Skórko et al., 1989). However, nothing is known about the possible role of polyP in archaea. A partially purified PPK was reported in S. acidocaldarius (Skórko et al., 1989). However, we demonstrated later that this protein was rather a glycogen synthase (Cardona et al., 2001). Despite the fact that no bacterial-type PPKs have been found in the majority of the available archaeal genomic sequences, we recently reported the isolation of a PPX enzyme from Sulfolobus solfataricus (Cardona et al., 2002). In the present work, we have studied the effect of different metals in several Sulfolobus species and have found that the presence of these cations decreased polyP levels and increased both PPX activity and phosphate efflux, clearly supporting the proposed metal tolerance model.

\section{METHODS}

Strains and growth conditions. S. metallicus DSM 6482 was grown at $65^{\circ} \mathrm{C}$ in medium 88 (Deutsche Sammlung von Mikroorganismen und Zellkulturen) with $0.05 \%(\mathrm{w} / \mathrm{v})$ elemental sulfur and $0.02 \%(\mathrm{w} / \mathrm{v})$ yeast extract. S. acidocaldarius DSM 639 was grown at $70{ }^{\circ} \mathrm{C}$ in the same medium but with $0 \cdot 1 \%(\mathrm{w} / \mathrm{v})$ yeast extract and $0 \cdot 2 \%(\mathrm{w} / \mathrm{v})$ sucrose, according to Skórko et al. (1989). S. solfataricus DSM 1617 was grown at $70^{\circ} \mathrm{C}$ in medium 182 (Deutsche Sammlung von Mikroorganismen und Zellkulturen) with $0 \cdot 1 \%(\mathrm{w} / \mathrm{v})$ yeast extract and $0 \cdot 1 \%(\mathrm{w} / \mathrm{v})$ Casamino acids. To study copper or cadmium tolerance of $S$. metallicus and S. solfataricus, the micro-organisms were grown in their respective media, except that different concentrations of $\mathrm{CuSO}_{4}(5-200 \mathrm{mM})$ or $\mathrm{CdSO}_{4}$ $(0.01-3 \mathrm{mM})$ were present initially, as indicated in the corresponding experiments. For shift experiments, S. metallicus cells were grown in the absence of copper to the early stationary phase and after removing the medium from the cells by centrifugation, they were then shifted to a new medium containing 10,20 or $100 \mathrm{mM}$ $\mathrm{CuSO}_{4}$. As a control, a shift of cells to $100 \mathrm{mM}\left(\mathrm{NH}_{4}\right)_{2} \mathrm{SO}_{4}$ was used. Aliquots were taken at different times and polyphosphate levels and PPX activity were determined. Growth was monitored by measuring unstained cell numbers by means of a Petroff-Hausser chamber under a phase-contrast microscope.

Electron microscopy. Unstained cells from S. metallicus or S. solfataricus were routinely examined for the presence of electron-dense bodies by transmission electron microscopy (Gonzalez \& Jensen, 1998). Early stationary-phase cells from different growth conditions were suspended in distilled water and then placed onto carboncoated nickel grids. After allowing the micro-organisms to settle on the grid, the excess liquid was drained off with filter paper, and the preparations were air-dried. For analysis, a transmission electron microscope (Philips Tecnai 12) operating at $80 \mathrm{kV}$ was used.

Electron energy loss spectroscopy (EELS). EELS analysis (Lünsdorf et al., 2000) was performed with a Zeiss CEM 902 integrated energy-filtered transmission electron microscope. The microscope was operated in the electron spectroscopic imaging (ESI) mode for element mapping, and parallel EELS performed for spectrum registration with the aid of ESI-Vision software (Soft Imagining System). Aperture settings described by Lünsdorf et al. (2000) were used. Commercial hydroxyapatite was used as the internal phosphate standard (Chávez et al., 2004).

PolyP quantification. Purified recombinant $\mathrm{His}_{6}-\mathrm{PPK}$ was prepared by using E. coli strain NR 100 as described previously (Ahn \& Kornberg, 1990; Kumble et al., 1996), and this preparation was used in the polyP assay described below. The protein concentration was determined by the method of Bradford (Coomassie Plus protein assay reagent, Pierce).

PolyP was quantified by using a two-step conversion of polyP into ATP by PPK and quantification of ATP by using luciferase to generate light (Ault-Riché et al., 1998). First, polyP was extracted by using Glassmilk, from the different cells grown in the absence or in the presence of copper once they reached the early stationary phase. The polyP extracted was assayed by using the reverse reaction of E. coli PPK in ADP excess. Finally, the ATP generated was determined by using the luciferase (Boehringer Mannheim) reaction, and the luminescence was measured with a luminometer (BioScan Lumi/96). Concentration of polyP was expressed in terms of $\mathrm{P}_{\mathrm{i}}$ residues.

In vitro preparation of $\left[{ }^{33} \mathrm{P}\right]$ poly $\mathrm{P}_{\mathbf{7 5 0}}$ as a substrate for PPX. Radioactively labelled polyP with a chain length of 750 residues was prepared as described by Ault-Riché et al. (1998), with the modifications of Cardona et al. (2001) and Alvarez \& Jerez (2004). The identity and purity of $\left[{ }^{33} \mathrm{P}\right]$ poly $\mathrm{P}_{750}$ were determined by its susceptibility to hydrolysis by ScPPX1 as described previously (Ault-Riché et al., 1998; Cardona et al., 2001).

Preparation of cell-free extracts from S. metallicus. Cells

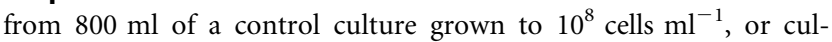
tures shifted to different $\mathrm{CuSO}_{4}$ concentrations or to $100 \mathrm{mM}$ $\left(\mathrm{NH}_{4}\right)_{2} \mathrm{SO}_{4}$, were harvested by centrifugation (7700 $\mathrm{g}$ for $15 \mathrm{~min}$ ). The pellets were washed with M88 medium to remove the sulfur.

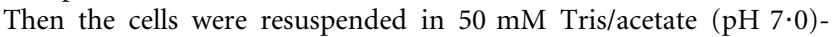
$10 \%$ sucrose buffer $(20 \mu \mathrm{l}$ per mg wet weight), frozen, and sonicated eight times for $30 \mathrm{~s}$ each time. The lysate was centrifuged $(4300 \mathrm{~g}$ for $5 \mathrm{~min}$ ) to eliminate cellular debris, and the supernatant was used to measure PPX activity. 
Assay for PPX activity and TLC analysis of the reaction products. PPX activity was determined as described by Cardona et al. (2002), with the following modifications. The $50 \mu \mathrm{l}$ reaction

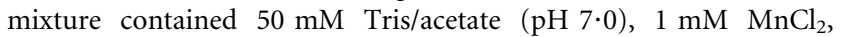
$100 \mathrm{mM} \mathrm{KCl}, 50 \mu \mathrm{g}$ extract protein and $250 \mu \mathrm{M}\left[{ }^{33} \mathrm{P}\right]$ polyP $\mathrm{P}_{750}$. After incubation of the mixture for $60 \mathrm{~min}$ at $65^{\circ} \mathrm{C}$, the reactions were stopped; $4 \mu \mathrm{l}$ was taken from each reaction mixture and loaded on polyethyleneimine-cellulose plates (Merck). For TLC, samples of $4 \mu \mathrm{l}$ were developed in $0 \cdot 75 \mathrm{M} \mathrm{KH}_{2} \mathrm{PO}_{4}(\mathrm{pH} \mathrm{3 \cdot 5)}$. Radioactive spots were visualized and quantified by using a Phosphorimager (Molecular Imager FX Systems, Bio-Rad). One unit of enzyme was defined as the amount releasing 1 pmol phosphate from polyP $\min ^{-1}$.

In vivo labelling of $\mathbf{S}$. metallicus with ${ }^{{ }^{32}} \mathbf{P}_{\mathbf{i}}$. Cells were grown in medium 88 supplemented with $0.05 \%(\mathrm{w} / \mathrm{v})$ sulfur and $0.02 \%$ $(\mathrm{w} / \mathrm{v})$ yeast extract to mid-exponential phase in $\mathrm{P}_{\mathrm{i}}$-sufficient conditions $\left(2 \mathrm{mM} \mathrm{P} \mathrm{P}_{\mathrm{i}}\right)$. Cells were collected by centrifugation and resuspended at a higher cell density $\left(10^{10}\right.$ cells $\left.\mathrm{ml}^{-1}\right)$ in a medium with a lower $\mathrm{P}_{\mathrm{i}}$ concentration $\left(0 \cdot 2 \mathrm{mM} \mathrm{P} \mathrm{P}_{\mathrm{i}}\right)$. To label the cells, ${ }^{32} \mathrm{H}_{3} \mathrm{PO}_{4}$ $\left[100 \mu \mathrm{Ci} \mathrm{ml}{ }^{-1}\left(3 \cdot 7 \mathrm{MBq} \mathrm{ml}^{-1}\right)\right]$ was added and the microorganisms were further incubated for $20 \mathrm{~h}$, after which the radioactively labelled cells were harvested by centrifugation.

$\mathbf{P}_{\mathbf{i}}$ efflux measurements. The ${ }^{32} \mathrm{P}_{\mathrm{i}}$-labelled cells were exhaustively washed (five times) by resuspension and centrifugation with fresh medium 88 containing sufficient $\mathrm{P}_{\mathrm{i}}(2 \mathrm{mM})$ to eliminate the nonincorporated radioactive label and finally were resuspended in the same medium to a cell density of $10^{8}$ cells $\mathrm{ml}^{-1}$, in the presence or absence of $\mathrm{CuSO}_{4}$. To determine the amount of ${ }^{32} \mathrm{P}_{\mathrm{i}}$ released to the medium, samples $(1.5 \mathrm{ml})$ were taken periodically and the supernatants obtained by their centrifugation at $12000 \mathrm{~g}$ for $10 \mathrm{~min}$ were measured by scintillation counting and analysed by TLC on polyethylenimine-cellulose with ${ }^{32} \mathrm{P}_{\mathrm{i}}$ as a standard (Keasling et al., 1993).

\section{RESULTS AND DISCUSSION}

\section{Accumulation of polyphosphate in members of the genus Sulfolobus}

We have previously described the presence of abundant polyP granules in the acidophilic A. ferrooxidans, which may be related to metal tolerance in this biomining bacterium (Alvarez \& Jerez, 2004). To detect the presence of these granules in members of the genus Sulfolobus, we analysed unstained cells of the micro-organisms by electron microscopy (Fig. 1a, b). When S. solfataricus (Fig. 1a) or S. acidocaldarius (not shown) was examined, very faint and small granules, if any, were present. In contrast, two or three large electron-dense granules per cell were seen in S. metallicus (Fig. 1b). To obtain detailed information about the polyphosphate-like inclusions, ultrastructural determinations were made by using scanning electron microscopy coupled to EELS analysis with an integrated energy-filtered transmission electron microscope. Fig. 1(c) shows the electron energy loss spectra obtained from cell areas containing granules in S. metallicus and in S. acidocaldarius compared with that for hydroxyapatite as a phosphate reference after background subtraction and spectrum filtering. The ionization energy onset of the $\mathrm{P}_{\mathrm{L} 2,3}$ edge is at $135 \mathrm{eV}$ for all three spectra, followed by characteristic energy-loss near edge structures (ELNES) features in the $50 \mathrm{eV}$ higher energy loss region (indicated by the bar in Fig. 1c). All three main maxima, i.e. I, II and III, were present in the spectra

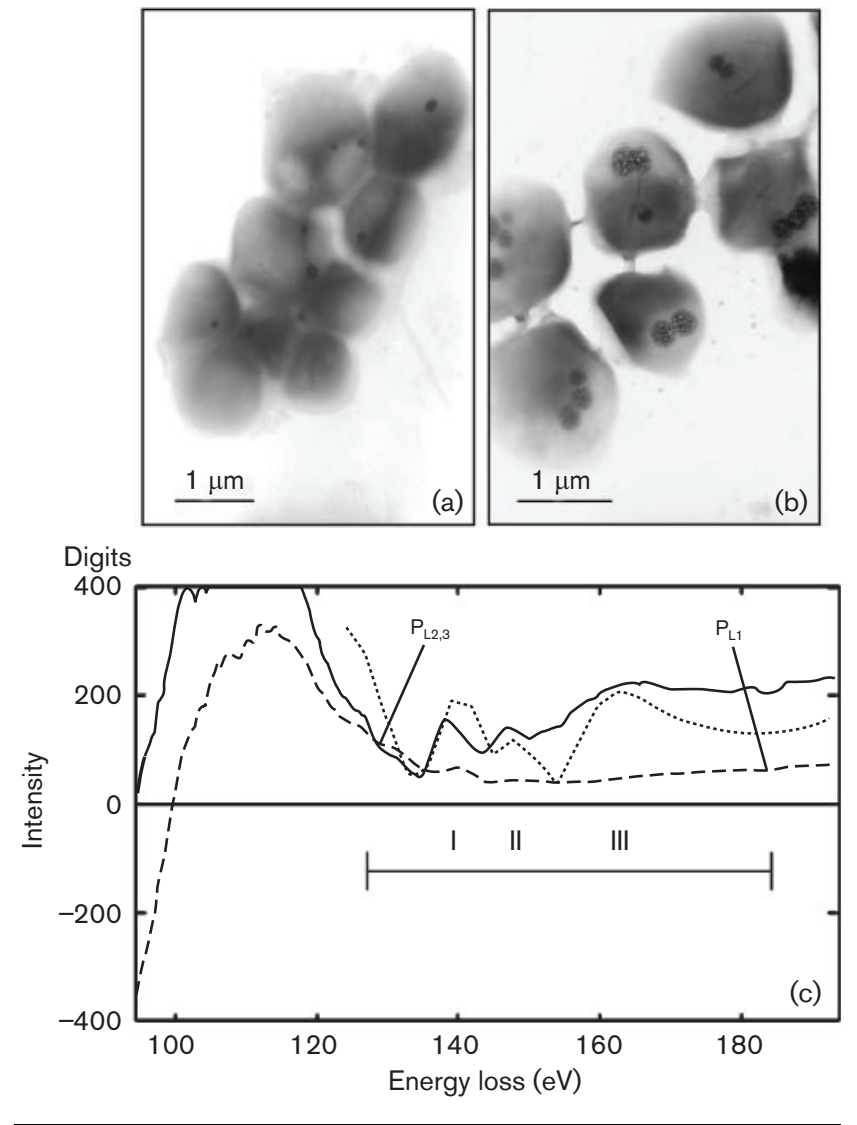

Fig. 1. Presence of electron-dense granules in members of the genus Sulfolobus. Cells of $S$. solfataricus (a) or S. metallicus (b) grown to the early stationary phase were analysed by electron microscopy. (c) Comparison of the spectra obtained for electron-dense granules from $S$. metallicus (full line) and $S$. acidocaldarius (dashed line), with hydroxyapatite (dotted line).

obtained, although the intensities in S. acidocaldarius were very small due to its low content of polyP granules, which was very similar to that of $S$. solfataricus (not shown). Thus, by using electron microscopic microanalyses we demonstrated that the electron-dense granules accumulated by $S$. metallicus were mainly composed of phosphate and most likely corresponded to polyP.

\section{Enzymic determinations of polyP}

To determine whether the electron-dense granules composed of phosphate were indeed due to a higher accumulation of polyP, we quantified polyP in S. metallicus, $S$. acidocaldarius and S. solfataricus during their growth phases (Fig. 2). Using cell-free extracts obtained for each growth time point, polyP was enzymically quantified. All three micro-organisms synthesized increasing amounts of polyP as growth proceeded, levelling off when the stationary phase was reached.

Accumulations of polyP in S. metallicus were remarkable for being so high and sustained in time compared to those in $E$. 

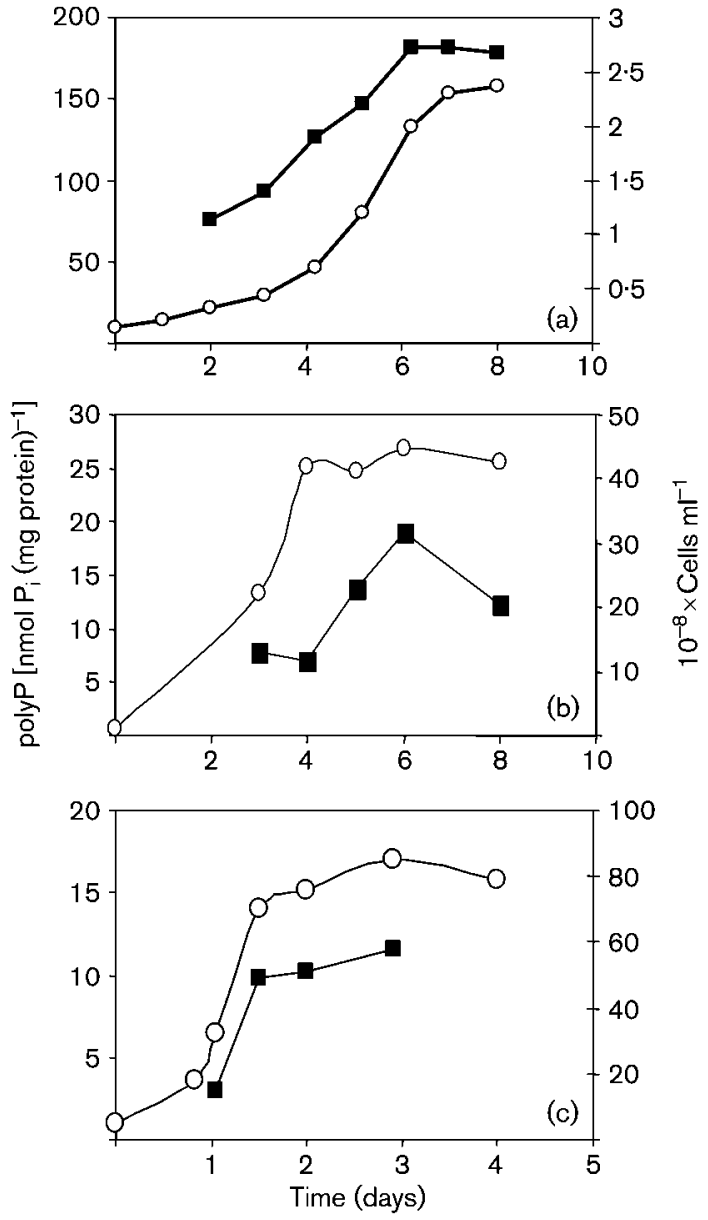

Fig. 2. PolyP levels during growth of different species of Sulfolobus. S. metallicus (a), S. solfataricus (b) and S. acidocaldarius (c) were grown in their respective media and the cell numbers $(\bigcirc)$ and polyP levels $(\boldsymbol{\square})$ were determined at the indicated times of growth.

coli, which does not form visible polyP granules under common growth conditions (Kornberg et al., 1999). The levels of $180 \mathrm{nmol}$ polyP (mg protein $)^{-1}(230 \mathrm{mM})$ reached at the stationary phase of growth (Fig. $2 \mathrm{a}$ ) are roughly 10fold greater than those seen in S. solfataricus $[20 \mathrm{nmol}$ polyP (mg protein $)^{-1}$ or $1 \mathrm{mM}$ ] (Fig. $2 \mathrm{~b}$ ) and S. acidocaldarius $[10 \mathrm{nmol} \text { polyP (mg protein) })^{-1}$ or $0.5 \mathrm{mM}$ ] (Fig. $2 \mathrm{c}$ ). The amounts of polyP accumulated by $S$. metallicus are even higher than those reported $\left(150 \mathrm{nmol} \mathrm{mg}{ }^{-1}\right)$ for another micro-organism accumulating polyP granules - Vibrio cholerae during the exponential phase of growth with a rich medium (Ogawa et al., 2000) - and are closer to the $400 \mathrm{nmol}$ (mg protein) ${ }^{-1}$ accumulated by A. ferrooxidans (Alvarez \& Jerez, 2004). It is possible that the polyP accumulations observed in these crenarchaea contribute not only to their energy supply but also to their enhanced survival and stress resistance in the presence of metals, as suggested for bacteria (Keasling, 1997; Alvarez \& Jerez, 2004).

\section{Effect of $\mathrm{CuSO}_{4}$ and $\mathrm{CdSO}_{4}$ in the growth of S. metallicus and $S$. solfataricus}

The S. metallicus cells utilized in these experiments were previously adapted to grow at different concentrations of metals. There was a small decrease in the growth rates and the curves reached the plateaus at slightly lower cell densities when the micro-organisms were grown in the presence of increasing $\mathrm{Cu}^{2+}$ concentrations compared with the control culture in the absence of added $\mathrm{Cu}^{2+}$ (Fig. 3a). However, at $200 \mathrm{mM} \mathrm{Cu}^{2+}$, there was a more severe effect of copper on growth, with an approximately $30 \%$ decrease in cell numbers. On the other hand, S. solfataricus was not able to grow in any of the copper concentrations tested (Fig. 3b). These results are in agreement with previous reports in which S. solfataricus was able to grow only in the presence of $0 \cdot 1-1 \cdot 0 \mathrm{mM}$ copper, being completely inhibited by growth in the presence of $10 \mathrm{mM}$ copper (Miller et al., 1992). This behaviour was similar to that seen for S. acidocaldarius, which also did not grow in the presence of $10 \mathrm{mM} \mathrm{Cu}^{2+}$ (Miller et al., 1992). These results clearly contrast with the very high tolerance of $S$. metallicus to concentrations of copper sulphate as high as 100 and $200 \mathrm{mM}$ (Fig. 3a). S. metallicus could grow in the presence of $\mathrm{CdSO}_{4}$ concentrations up to $1 \mathrm{mM}$ without a noticeable effect in the cell numbers obtained at the stationary phase. At higher concentrations (2-3 mM) there was an extended lag period and the culture reached significantly lower cell numbers (results

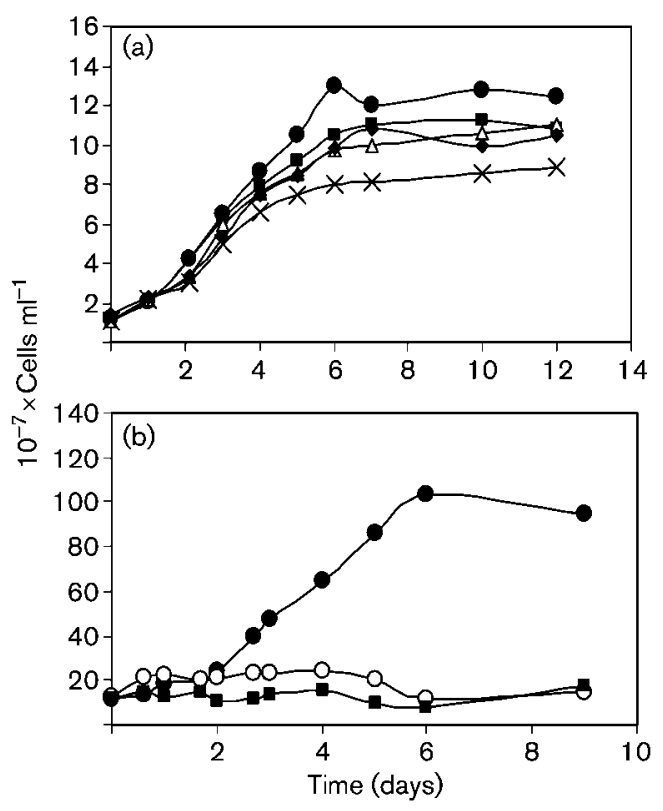

Fig. 3. Growth of Sulfolobus species in the presence of $\mathrm{CuSO}_{4}$. S. metallicus (a) and S. solfataricus (b) cells were inoculated in their respective growth media in the absence of added $\mathrm{CuSO}_{4}(\bullet)$, or were supplemented with $5 \mathrm{mM}(\bigcirc)$, $10 \mathrm{mM}(\boldsymbol{\square}), 50 \mathrm{mM}(\triangle), 100 \mathrm{mM}(\boldsymbol{\Delta})$ or $200 \mathrm{mM}(\boldsymbol{X}) \mathrm{CuSO}_{4}$, and cells were counted daily. 

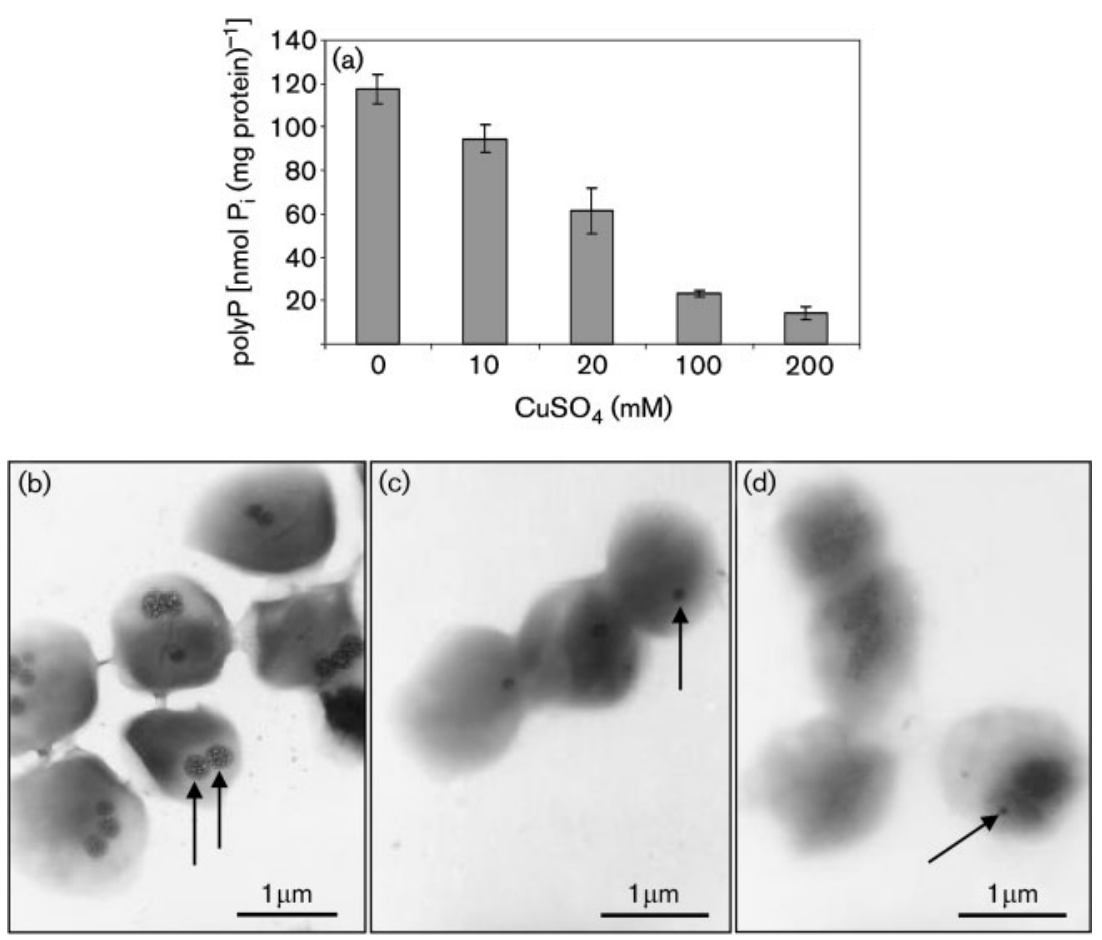

Fig. 4. Reduction in polyP content during exposure of $S$. metallicus to copper ions. (a) Cells grown in the absence or presence of the $\mathrm{CuSO}_{4}$ concentrations indicated were harvested in the early stationary phase (6-7 days of growth) and polyP was quantified by the non-radioactive enzymic method. Three independent determinations were performed. The error bars represent the standard deviations. (b-d) Cells harvested from the same cultures as shown in Fig. 3(a) in the absence of $\mathrm{CuSO}_{4}$ (b), or in the presence of $100 \mathrm{mM}$ (c) or $200 \mathrm{mM}$ (d) $\mathrm{CuSO}_{4}$, were analysed by electron microscopy without staining. Arrows indicate some of the polyP granules. not shown). On the other hand, S. solfataricus growth was seriously affected by $\mathrm{CdSO}_{4}$ concentrations as low as $10 \mu \mathrm{M}$ (results not shown).

\section{Effect of copper ions on the levels of polyP in S. metallicus}

PolyP levels showed a gradual decrease with increasing concentration of copper in the growth medium of S. metallicus until a clear drop (more than $90 \%$ ) was seen when the $\mathrm{Cu}^{2+}$ concentration was raised to $200 \mathrm{mM}$ (Fig. 4a). This behaviour correlated exactly with the disappearence of the polyP granules observed when cells were subjected to those high copper levels (Fig. 4b, c, d). In the absence of copper, $96 \%$ of the cells contained two or three large polyP granules per cell (Fig. 4b), whereas at $200 \mathrm{mM}$ copper sulphate the granules were very small, with only $46 \%$ of the cells containing only one of these aggregates (Fig. 4d). These results strongly indicate a possible relationship between the polyP levels and the adaptation of $S$. metallicus to grow in the presence of $\mathrm{Cu}^{2+}$.

\section{PPX activity in cell-free extracts after addition of different concentrations of metals}

A possible mechanism to explain the observed decrease in polyP levels when cells were exposed to copper ions was an increase of the PPX activity. Therefore, the in vitro effect of copper and other metals on the PPX activity present in cellfree extracts of non-adapted S. metallicus was determined (Fig. 5). Copper greatly stimulated PPX activity at very low concentrations. The same maximal PPX activity was reached with both copper and manganese. However, the metal concentration requirement for this was $10 \mu \mathrm{M}$ for copper (Fig. 5) and $500 \mu \mathrm{M}$ for manganese (results not shown). At concentrations of copper higher than $10 \mu \mathrm{M}$ there was an inhibition of the activity, whereas manganese continued to stimulate PPX. Other metals such as cadmium and zinc also stimulated PPX activity in the micromolar range although to a lower extent (results not shown). These results suggest a stimulatory effect of copper and other metal ions on PPX activity and polyP hydrolysis.

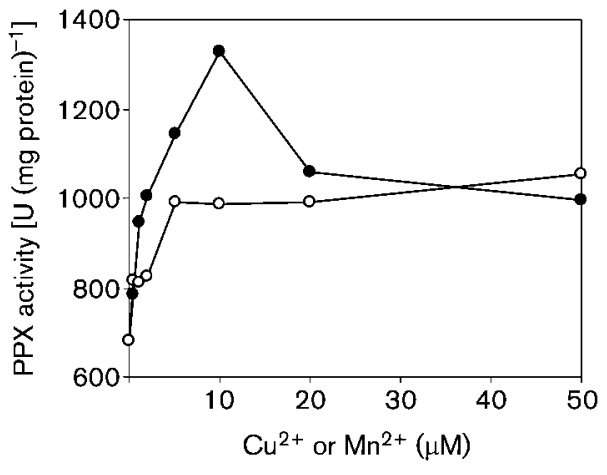

Fig. 5. PPX response to $\mathrm{CuSO}_{4}$ in vitro. PPX activity was determined using the standard assay with cell-free extracts from $S$. metallicus grown in the absence of copper. The indicated amounts of $\mathrm{MnSO}_{4}(\bigcirc)$ or $\mathrm{CuSO}_{4}(\mathbf{O})$ were added to the assay reaction mixtures. 


\section{PPX activity and polyP levels of non-adapted cells exposed to different copper concentrations}

To further investigate the effect of copper ions on PPX activity and polyP levels, non-adapted cells were shifted to the presence of different $\mathrm{CuSO}_{4}$ concentrations. Cells were collected at different time intervals and the PPX activity and polyP levels were measured in the cell-free extracts. A rapid increase in the PPX activity was seen when cells were exposed to copper, with the severest effect at the $100 \mathrm{mM}$ concentration (Fig. 6a). No significant effect on PPX activity or polyP levels was seen when the cells were shifted to $100 \mathrm{mM}\left(\mathrm{NH}_{4}\right)_{2} \mathrm{SO}_{4}$ (results not shown). The increase in PPX activity corresponded in time with the decrease in polyP levels seen in Fig. 6(b), strongly suggesting that the decrease in polyP levels observed when cells were shifted to the presence of copper was due to an increase of this PPX activity.

\section{Effect of copper ions on the efflux of $P_{i}$ from S. metallicus cells}

The decrease in polyP levels due to increased PPX activity in S. metallicus cells subjected to $\mathrm{Cu}^{2+}$ should generate free $\mathrm{P}_{\mathrm{i}}$.
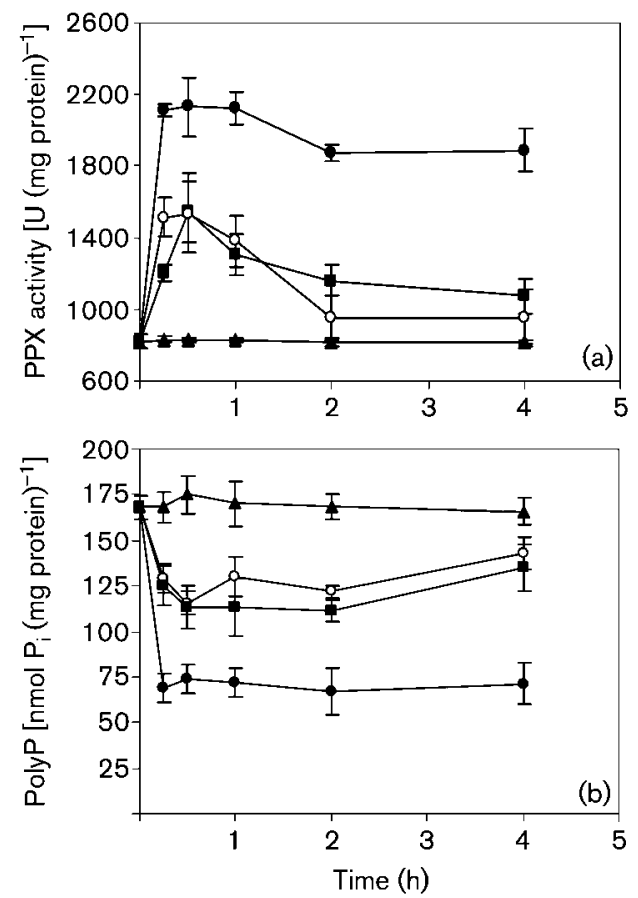

Fig. 6. PPX activity and polyP content of cells exposed to copper ions. S. metallicus cells were grown in the absence of copper to the early stationary phase. Cells were then shifted to a fresh medium containing no $\mathrm{CuSO}_{4}(\boldsymbol{\Delta}), 10 \mathrm{mM}(\bigcirc), 20 \mathrm{mM}$ (ם) or $100 \mathrm{mM}(\mathbf{0})$ copper or to $100 \mathrm{mM}\left(\mathrm{NH}_{4}\right)_{2} \mathrm{SO}_{4}$ as a control (not shown). Aliquots were taken at the indicated times, and PPX activity (a) and polyP (b) were determined. Means \pm SE $(n=4)$ are plotted.
To determine whether this $\mathrm{P}_{\mathrm{i}}$ was transported out of the cells, S. metallicus was grown to early stationary phase and labelled in vivo with ${ }^{32} \mathrm{P}_{\mathrm{i}}$ as indicated in Methods. After exhaustively washing the radioactively labelled cells to eliminate the non-incorporated label, they were resuspended in sulfur medium with or without $\mathrm{Cu}^{2+}$ ions and the $\mathrm{P}_{\mathrm{i}}$ efflux was determined (Fig. 7).

There was a continuous basal release of label from the control cells. However, an increase in the $\mathrm{P}_{\mathrm{i}}$ efflux over this basal level was observed when cells were exposed to $\mathrm{Cu}^{2+}$ ions. Differences between the kinetics and extent of polyP degraded (Fig. 6) and the $\mathrm{P}_{\mathrm{i}}$ released (Fig. 7) were observed. A similar situation has been found in Acinetobacter johnsonii subjected to conditions (anaerobiosis) in which $65 \%$ of the polyP is degraded, since intracellular $\mathrm{P}_{\mathrm{i}}$ accumulated up to $150 \mathrm{mM}$ in the course of polyP degradation, while the external $\mathrm{P}_{\mathrm{i}}$ concentration remained below $11 \mathrm{mM}$. The amount of ${ }^{32} \mathrm{P}_{\mathrm{i}}$ released to the medium was the highest in cells exposed to $200 \mathrm{mM} \mathrm{Cu}^{2+}$. By analysing the radioactivity released to the medium by TLC on polyethyleneimine-cellulose we found that it consisted mainly of $\mathrm{P}_{\mathrm{i}}$ (not shown). No other radioactively labelled cellular metabolites appeared on the TLC, indicating that the label released to the medium was not the product of cellular lysis during the treatment with copper. These results strongly suggest that at least part of the $\mathrm{P}_{\mathrm{i}}$ generated from polyP hydrolysis in the presence of $\mathrm{Cu}^{2+}$ ions was transported out of the cells. Formation and transport of metal-phosphate complexes have been demonstrated in cells or isolated membrane vesicles from bacteria by determination of changes in the membrane potentials (van Veen et al., 1994). This type of system is not currently available in S. metallicus. Our attempts to label S. metallicus cells with ${ }^{64} \mathrm{Cu}$ to determine

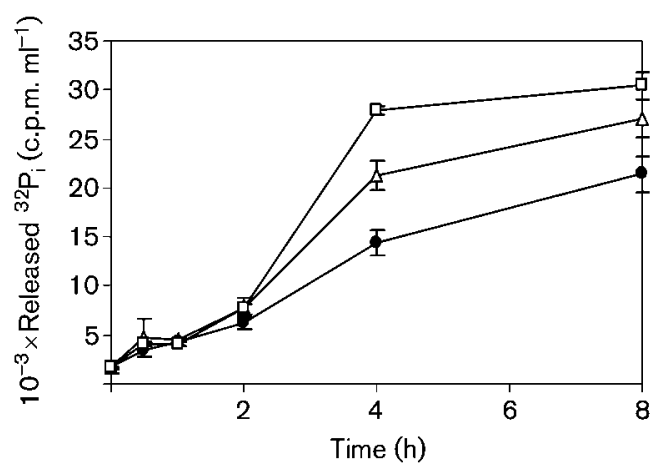

Fig. 7. Effect of copper ions on the efflux of $\mathrm{P}_{\mathrm{i}}$ from $S$. metallicus cells. Cells were labelled in vivo with $\mathrm{H}_{3}{ }^{32} \mathrm{PO}_{4}$ [100 mCi ml $\left.\mathrm{mb}^{-1}\left(3.7 \mathrm{MBq} \mathrm{ml}^{-1}\right)\right]$ for $20 \mathrm{~h}$ in the presence of $0.2 \mathrm{mM} \mathrm{P}_{\mathrm{i}}$. The cells were then exhaustively washed with cold standard medium and shifted to the same fresh medium with no copper added $(\bullet)$, or containing $100 \mathrm{mM}(\triangle)$ or $200 \mathrm{mM}$ ( $\square) \mathrm{CuSO}_{4}$. At the times indicated, the cells were removed by centrifugation and the radioactive $P_{i}$ released to the medium supernatants was determined. Means \pm SE $(n=4)$ are plotted. 
the formation of metal-phosphate complexes were unsuccessful, probably due to competing protons in the acidic environment of this acidophile. Therefore, we could not determine the efflux of the metal from the cells. Until the formation of copper-phosphate complexes is demonstrated in S. metallicus, we cannot rule out that copper may be exerting an indirect effect that alters polyP levels.

It is possible that the proposed model for polyP-mediated metal detoxification also operates in S. acidocaldarius and S. solfataricus. However, their very low levels of polyP synthesized compared to those in S. metallicus make this system less relevant in the former micro-organisms, since they are very sensitive to copper (Dopson et al., 2003), as we have also seen here. The low levels of polyP in S. acidocaldarius and S. solfataricus are not due to lack of phosphate, because in their natural environments, such as Octopus Spring at Yellowstone National Park or the thermal waters from Pozzo Vasca at Vulcano in the Aeolian Islands, southern Italy, phosphate has been found in different ionic forms depending on the $\mathrm{pH}$ of the medium (Amend \& Shock, 2001).

The proposed model for metal ion detoxification based on the hydrolysis of polyP involves the transport of metalphosphate complexes out of the cell. It has been proposed that the inorganic phosphate transport (Pit) system could be a possible candidate for this purpose, because it can reversibly transport metal-phosphate complexes (Keasling, 1997; van Veen, 1997). A Pit-like phosphate transport system was searched for in the available genomes of S. solfataricus, Sulfolobus tokodaii and S. acidocaldarius. A Pit-like transporter was not found in these archaea, but instead we found an open reading frame encoding a protein similar to the Pho84 $\mathrm{P}_{\mathrm{i}}$ transporter from Saccharomyces cerevisiae. Experimental evidence indicates that yeast Pho84, as Pit does, transports metal-phosphate complexes (Persson et al., 2003). Pho84, like Pit, belongs to the family of $\mathrm{P}_{\mathrm{i}}: \mathrm{H}^{+}$ symporters and is a member of the major facilitator superfamily (Pao et al., 1998). The Pho84 transporter is functional only in acidic environmental conditions (Persson et al., 2003). Currently there is no evidence for a Pho84-like transporter in S. metallicus. However, it is interesting that only proteins similar to Pho84 were present in all the available genomes of acidophilic archaea: Sulfolobus tokodaii, S. solfataricus, S. acidocaldarius, Thermoplasma acidophilum, Thermoplasma volcanicum and F. acidarmanus.

The P-type CPX-ATPases are responsible for the transport of heavy metal ions in archaea, bacteria and eukaryotes (Pedone et al., 2004). In S. solfataricus, a putative coppertransporting ATPase, CopA, has been recently expressed, isolated and its catalytic domain crystallized (Deigweiher et al., 2004). CopB and CopZ have been studied recently in F. acidarmanus (Baker-Austin et al., 2005). Although a genomic DNA sequence is not available yet for S. metallicus, our results suggest that this archaeon might have a copper homeostasis similar to that of other micro-organisms; however, no experimental evidence supporting this proposal is available. Irrespective of the possible existence of such metal cation uptake and efflux mechanisms, it is plausible that a polyP-mediated metal tolerance mechanism such as the one recently described for the metal-resistant polyPaccumulating acidophilic bacterium A. ferrooxidans (Alvarez \& Jerez, 2004) is also of great functional significance for the survival of an extremophilic biomining archaeon such as S. metallicus.

\section{ACKNOWLEDGEMENTS}

This research was supported in part by project ICM P-99-031-F. F. R. was the recipient of a CONICYT scholarship. We are very grateful to Arthur Kornberg for kindly providing us with E. colistrains NR129 and NR100 in order to obtain $\left[{ }^{32} \mathrm{P}\right]$ poly $\mathrm{P}_{750}$, to $\mathrm{H}$. Lünsdorf for the EELS analysis and to Mauricio González and Angélica Reyes for their help with the microbial labelling of cells with ${ }^{64} \mathrm{Cu}$.

\section{REFERENCES}

Ahn, K. \& Kornberg, A. (1990). Polyphosphate kinase from Escherichia coli. Purification and demonstration of a phosphoenzyme intermediate. J Biol Chem 256, 11734-11739.

Aiking, H., Stijnman, A., van Garderen, C., van Heerikhuizen, H. \& van't Riet, J. (1984). Inorganic phosphate accumulation and cadmium detoxification in Klebsiella aerogenes CTC 418 growing in continuous culture. Appl Environ Microbiol 47, 374-377.

Akiyama, M., Crooke, E. \& Kornberg, A. (1992). The polyphosphate kinase gene of Escherichia coli. Isolation and sequence of the ppk gene and membrane location of the protein. J Biol Chem 267, 22556-22561.

Akiyama, M., Crooke, E. \& Kornberg, A. (1993). An exopolyphosphatase of Escherichia coli. The enzyme and its $p p x$ gene in a polyphosphate operon. J Biol Chem 268, 633-639.

Alvarez, S. \& Jerez, C. A. (2004). Copper ions stimulate polyphosphate degradation and phosphate efflux in Acidithiobacillus ferrooxidans. Appl Environ Microbiol 70, 5177-5182.

Amend, J. P. \& Shock, E. L. (2001). Energetics of overall metabolic reactions of thermophilic and hyperthermophilic Archaea and Bacteria. FEMS Microbol Rev 25, 175-243.

Ault-Riché, D., Fraley, C. D., Tzeng, C.-M. \& Kornberg, A. (1998). A novel assay reveals multiple pathways regulating stress-induced accumulations of inorganic polyphosphate in Escherichia coli. J Bacteriol 180, 1841-1847.

Baker-Austin, C., Dopson, M., Wexler, M., Sawers, R. G. \& Bond, P. L. (2005). Molecular insight into extreme copper resistance in the extremophilic archaeon Ferroplasma acidarmanus Fer1. Microbiology 151, 2637-2646.

Cardona, S. T., Remonsellez, F., Guiliani, N. \& Jerez, C. A. (2001). The glycogen-bound polyphosphate kinase from Sulfolobus acidocaldarius is actually a glycogen synthase. Appl Environ Microbiol 67, 4773-4780.

Cardona, S. T., Chávez, F. P. \& Jerez, C. A. (2002). The exopolyphosphatase gene from Sulfolubus solfataricus: characterization of the first gene found to be involved in polyphosphate metabolism in Archaea. Appl Environ Microbiol 68, 4812-4819.

Chávez, F. P., Lünsdorf, H. \& Jerez, C. A. (2004). Growth of polychlorinated-biphenyl-degrading bacteria in the presence of biphenyl and chlorobiphenyls generates oxidative stress and massive 
accumulation of inorganic polyphosphate. Appl Environ Microbiol 70, 3064-3072.

Deigweiher, K., Drell, I. V. T. L., Prutsch, A., Scheidig, A. J. \& Lübben, M. (2004). Expression, isolation, and crystallization of the catalytic domain of CopB, a putative copper transporting ATPase from the thermoacidophilic archaeon Sulfolobus solfataricus. J Bioenerg Biomemr 36, 151-159.

Dopson, M., Baker-Austin, C., Koppineedi, P. R. \& Bond, P. L. (2003). Growth in sulfidic mineral environments: metal resistance mechanisms in acidophilic microorganisms. Microbiology 149, 1959-1970.

Ettema, T. J., Huynen, M. A., de Vos, W. M. \& van der Oost, J. (2003). TRASH: a novel metal-binding domain predicted to be involved in heavy-metal sensing, trafficking and resistance. Trends Biochem Sci 28, 170-173.

Gonzalez, H. \& Jensen, T. E. (1998). Nickel sequestering by polyphosphate bodies in Staphylococcus aureus. Microbios 106, 179-185.

Harwood, V. J. \& Gordon, A. S. (1994). Regulation of extracellular copper-binding proteins in copper-resistant and copper-sensitive mutants of Vibrio alginolyticus. Appl Environ Microbiol 60, 1749-1753.

Keasling, J. D. (1997). Regulation of intracellular toxic metals and other cations by hydrolysis of polyphosphate. Ann N Y Acad Sci 829, 242-249.

Keasling, J. D. \& Hupf, G. A. (1996). Genetic manipulation of polyphosphate metabolism affects cadmium tolerance in Escherichia coli. Appl Environ Microbiol 62, 743-746.

Keasling, J. D., Bertsch, L. \& Kornberg, A. (1993). Guanosine pentaphosphate phosphohydrolase of Escherichia coli is a long-chain exopolyphosphatase. Proc Natl Acad Sci U S A 90, 7029-7033.

Kornberg, A., Rao, N. N. \& Ault-Riché, D. (1999). Inorganic polyphosphate: a molecule of many functions. Annu Rev Biochem 68, 89-125.

Kumble, K. D., Ahn, K. \& Kornberg, A. (1996). Phosphohistidyl active sites in polyphosphate kinase of Escherichia coli. Proc Natl Acad Sci U S A 93, 14391-14395.

Lünsdorf, H., Strömpl, C., Osborn, A. M., Bennasar, A., Moore, E. R. B., Abraham, W.-R. \& Kenneth, N. T. (2000). Approach to analyze interactions of microorganisms, hydrophobic substrates, biofilms and to study initial events in microbiogeological processes. Methods Enzymol 336, 317-331.

Miller, K. W., Risanico, S. S. \& Risatti, J. B. (1992). Differential tolerance of Sulfolobus strains to transition metals. FEMS Microbiol Lett 93, 69-74.

Ogawa, N., Tzeng, C. M., Fraley, C. D. \& Kornberg, A. (2000). Inorganic polyphosphate in Vibrio cholerae: genetic, biochemical and physiologic features. J Bacteriol 182, 6687-6693.

Pao, S. S., Paulsen, I. T. \& Saier, M. H, Jr (1998). Major facilitator superfamily. Microbiol Mol Biol Rev 62, 1-34.

Pedone, E., Bartolucci, S. \& Fiorentino, G. (2004). Sensing and adapting to environmental stress: the archaeal tactic. Front Biosci 9, 2909-2926.

Persson, B. L., Lagerstedt, J. O., Pratt, J. R., Pattison-Granberg, J., Lundh, K., Shokrollahzadeh, S. \& Lundh, F. (2003). Regulation of phosphate acquisition in Saccharomyces cerevisiae. Curr Genet 43, 225-244.

Rouch, D. R., Lee, B. T. \& Camakaris, J. (1989). Genetics and molecular basis of copper resistance in Escherichia coli. In Metal Homeostasis, pp. 439-446. Edited by D. H. Hamer \& D. R. Winge. New York: Alan Liss.

Scherer, P. A. \& Bochem, H. P. (1983). Ultrastructural investigation of 12 Methanosarcinae and related species grown on methanol for occurrence of polyphosphatelike inclusions. Can J Microbiol 29, 1190-1199.

Silver, S. \& Phung, L. T. (1996). Bacterial heavy metal resistance: new surprises. Annu Rev Microbiol 50, 753-789.

Skórko, R., Osipiuk, J. \& Stetter, K. O. (1989). Glycogen-bound polyphosphate kinase from the archaebacterium Sulfolobus acidocaldarius. J Bacteriol 171, 5162-5164.

van Veen, H. W. (1997). Phosphate transport in prokaryotes: molecules, mediators and mechanisms. Antonie van Leeuwenhoek 72, 299-315.

van Veen, H. W., Abee, T., Kortstee, G. J. J., Konings, W. N. \& Zehnder, A. J. B. (1994). Translocation of metal phosphate via phosphate inorganic transport system of Escherichia coli. Biochemistry 33, 1766-1770. 